\title{
CYP2C19*12 Allele
}

National Cancer Institute

\section{Source}

National Cancer Institute. CYP2C19*12 Allele. NCI Thesaurus. Code C46013.

Human CYP2C19*12 allele is located within 10q24.1-q24.3 and is approximately $90 \mathrm{~kb}$ in length. This allele, a variant form of the CYP2C19 wild-type allele, encodes cytochrome P450 2C19*12 protein. The CYP2C19*12 allele exhibits a clinically-relevant SNP (c.1473A>C) in exon 9 that results in a X491C coding change. This alteration yields an unstable cytochrome $\mathrm{P} 4502 \mathrm{C} 19 * 12$ protein that is predicted to have an additional 26 amino acids. 